\title{
ADLİ DİŞ HEKİMLİĞİNDE GÜNCEL YAKLAŞIMLAR
}

\section{LATEST APPROACHES IN FORENSIC DENTISTRY}

\author{
Dr. Dt. Feryal KARAMAN*
}

Makale Kodu/Article code: 3958

Makale Gönderilme tarihi: 15.01 .2019

Kabul Tarihi: 17.05 .2019

Feryal Karaman: ORCID ID: 0000-0003-0219-0074

DOI : $10.17567 /$ ataunidfd.566892

\section{öz}

Adli diş hekimliği gelişmeye çok açık olan bir diş hekimliği dalıdır. Dişler ve dişsel özelliklerin eşsiz olması ve her türlü şartta uzun süre bozulmadan kalabilmesi adli diş hekimliğinin önemini arttırmaktadır. Bu alanın en önemli çalışmalarından biri, kimliklendirmedir. Dişlerden ve çene kemiğinden edinilen bilgilerle kişinin ırkı, cinsiyeti, yaşı tespit edilebilir. Kimlik tespitinde diş kayıtlarının önceden tutulmuş ve saklanmış olmasının büyük önemi vardır. Ayrıca, ağız ve dișlerin incelenmesiyle ısırık izi analizi, dudak-damak izi analizi ve travma hasarlarının tespiti gibi konular da çözümlenebilmektedir. Isırık izleri parmak izleri gibi benzersizdir ve kimliklendirmede başarıyla kullanılmaktadır. Kimliklendirme ölü veya canlı kişinin muayenesi ile yapılabildiği gibi insan vücuduna ait bir parçanın, bir dokunun, iz ve belirtilerin incelenmesiyle de yapılabilir. Dişler dış etkenlere karşı dayanıkıdırlar ve çene kemiği içinde korunmaktadırlar. Bu nedenle dentin ve pulpada korunan hücrelerden uzun yıllar sonra bile DNA elde edilmektedir. Özellikle kimliği belli olmayan kişilerde dişsel özellikler, yapılmış olan tedavi ve protezler kişinin kimliğinin belirlenmesinde önemli rol oynar. Tanınmayacak şekilde yanmış, parçalanmış veya ölüm sonrası değişikliklere maruz kalmış cesetlerin kimlik tespitinde dişler birinci derecede öneme sahiptir. Kişinin ırkını, cinsiyetini ve yaşını belirlemek için çeşitli metotlar geliştirilmiştir. Yaş belirlemede gençlerde radyolojik teknikler, daha ileri yaşlarda ise morfolojik, histolojik ve kimyasal teknikler kullanılmaktadır. Bu teknikler her yıl ilerlemekte ve yenileri eklenmektedir.

Diş hekimliği fakültelerinde adli diş hekimliği dersi verilmediği için bu formasyon eksiktir. Ancak her diş hekiminin mesleğiyle ilgili konuları bilme ve gelişmeleri takip etme sorumluluğu vardır. Bu makale adli diş hekimliğinde kullanılan ve bilinen metotlar üzerinde geliştirilen yenilikler ve en son fikirler üzerine bir değerlendirme sağlamaktadır.

Anahtar kelimeler: Adli diş hekimliği, Dental kimliklendirme, Dental görüntüleme, Isırık izleri,

\section{ABSTRACT}

Forensic odontology is a dentistry branch which is highly open to development. The fact that teeth and dental features are unique and that these properties can be retained for long periods without deterioration under any circumstances, enhances the importance of forensic dentistry studies. One of the most important works of this field is, identification. The race, sex and age of a person can be determined by the information obtained from the teeth and jaw bone. Pre-recorded and stored dental records have a great importance in identification. In addition, by the examination of the mouth and teeth, some issues such as bite mark analysis, lip-palate analysis and trauma damage detection, can be solved. Bite marks are unique as fingerprints and are used successfully in identification. Identification can be done by examination of a dead or living person, as well as by examining a part of a human body, a tissue and some traces. The teeth are resistant to external factors and are protected in the jaw bone. For this reason, DNA is still obtained after many years from the protected dentine and pulp cells. Especially in the identification of unknown persons, the dental properties, the treatments and protheses play a very important role in determining the identity of that person. The teeth are of primary importance in the identification of unrecognized bodies that have been burned, fragmented or exposed to post-mortem changes. Various methods have been developed to determine the race, sex and age of the individual. In the determination of age, radiological techniques are used in young people and morphological, histological and chemical techniques are used in older ages. These techniques are progressing every year and new ones are added.

Forensic dentistry lectures is not given in dentistry faculties and so this formation is incomplete. However, each dentist has the responsibility to know the issues related to the profession and to follow the developments. This article provides an assessment of the latest ideas which have been developed on known methods used in forensic dentistry.

Key words: Forensic dentistry, Dental identification, Dental imaging, Bite marks

*İstanbul Üniversitesi Cerrahpaşa, Adli Tıp Enstitüsü, Fatih, İstanbul

Kaynakça Bilgisi: Karaman F. Adli Diş Hekimliğinde Güncel Yaklaşımlar. Atatürk Üniv Diş Hek Fak Derg 2020; 30: 492-98.

Citation Information: Karaman F. Latest Approaches in Forensic Dentistry. J Dent Fac Atatürk Uni 2020; 30: 492-98. 


\section{GİRIŞ}

Dişler, insan vücudundaki en sert ve dirençli dokulardır. Suda kalma, gömülme, çürüme ve benzeri çeşitli doğal şartlara maruz kalma veya büyük kitlesel kazalardaki parçalanma, yanma gibi durumlara karşı oldukça dirençlidirler. Dişsel özellikler her kişi için özeldir. Bu benzersizlik diş hekimleri tarafından yapılan kişiye özel tedaviler nedeniyle de önem kazanmaktadır. ${ }^{1,2}$ Bu nedenle eğer dental kayıtlar mevcut ise, kişinin dentisyonu kimlik belirleme ve karşılaştırma için çok önemlidir. ${ }^{3}$

Post mortem değişiklikler, travmatik doku yaralanmaları durumlarında veya parmak izi kayıtlarının mevcut olmaması halinde, adli dental kimlik belirleme (identifikasyon) diğer görsel metotları geçersiz kılar ve kimlik belirlenmesinde çok önemli bir rol oynar. ${ }^{4}$ Adli diş hekimliğinin tarihi çok eskilere dayanmaktadır. Çok eski yıllarda da mahkemelerde dental delillerin sıklıkla kullanıldığı bilinmektedir. Adli diş hekimliğinde kullanılan teknikler de teknolojinin gelişmesine paralel olarak yenilenmektedir. ${ }^{5}$

Adli diş hekimliğinin başlıca kullanım alanları şunlardır:

1. Diş, çene ve yumuşak doku yaralanmalarının incelenmesi ve değerlendirilmesi.

2. Özellikle kitle kazalarında ve kriminal olaylarda ölen kişilerin kimliklerinin belirlenmesi.

3. Kronolojik yaşı net olarak bilinmeyen veya şüphe olan kişilerin yaşlarının belirlenmesi

4. Kavgalarda, cinsel saldırılarda, çocuk tacizi vakalarında sıklıkla rastlanan ısırık izlerinin tanımlanması, incelenmesi ve değerlendirilmesi. ${ }^{6}$

Kişilerde kimlik belirlenmesinde kullanılan yaygın metotlar görsel metotlardır ki bunlar vücut yapısı, kilosu, yaşı, saçlarının varlığı veya yokluğu gibi görsel özellikler, protez, ampütasyon, implant, yara izi, döğme, doğum lekesi gibi tıbbi işaretler ve ayak izi, parmak izi, DNA profili ve dentisyon gibi kişisel özelliklerdir. ${ }^{4}$ Bunların arasında dental kimliklendirme daha önemlidir, çünkü kişi iskelet haline gelmiş, çürümüş, yanmış, parçalanmış olsa bile dental dokular korunmaktadır. Bu yüzden dental dokular mağdur veya şüpheli olan kişinin yaşı, cinsiyeti ve etnik kökenini belirlemek için kullanılabilir.

Adli dental kimliklendirmede kullanılan teknikler ve veri toplama metotları yıllar içinde önemli değişimler geçirmiştir. Daha önce kullanılan ve bilinen metotlar üzerine yenilikler katılarak ve geliştirilerek dental görüntüleme teknikleri, ısırık izi analizleri, oral dokular kullanılarak yapılan DNA analizleri, şelioskopi ve rugoskopi gibi yöntemler de geliştirilmiştir. Aynı zamanda son zamanlarda fasial rekonstrüksiyon, protez tanımlanması, mukayese mikroskopu ve dil izi incelemeleri de adli diş hekimliğine katılmış yeniliklerdir. Bu makale adli diş hekimliğinde kullanılan ve bilinen metotlar üzerinde geliştirilen yeniliklerin ve en son fikirlerin gözden geçirilmesi ve değerlendirilmesini amaçlamaktadır.

\section{1- Adli diş hekimliğinde kullanılan bilinen metotlardaki gelişmeler: \\ A - Dental kayıtlar:}

Adli dental kimliklendirme çoğunlukla ölüm öncesi dental kayıtların varlığına, yeterliliğine ve doğruluğuna bağlıdır. Dental kayıtların devamlı tutulması diş hekiminin vazifesidir ve esas olan, bu kayıtların hastalar ve hekimler için bir bilgi kaynağı olarak adli ve tıbbi amaçlara hizmet etmesidir. Karşılaştırmalı dental analizin de kimlik belirlemede parmak izi ve DNA analizi gibi önemli rolü vardır. Dental kayıtlardan 2001 New York'taki Dünya Ticaret Merkezi'ne yapılan terörist saldırıda ve 2004 Hint Okyanusundaki Tsunami vakası gibi pek çok kitlesel felaketlerde başarılı bir şekilde faydalanıldı. Bu kayıtlar röntgenler, fotoğraflar, modeller, notlar ve dental şemalar gibi muhtelif şekilerde mevcuttur. Dental kayıtların tutulması batılı ülkelerde bir zorunluluktur. Kayıtların saklanması konusunda farklı ülkelerde farklı kurallar vardır. ${ }^{7}$

Bilgisayar ortamında tutulmuş olan kayıtlar, dental kimliklendirme için diş kayıtlarının gerektiği adli vakalarda veya rutin profesyonel konsültasyonlarda kolaylıkla ulaşılabilmesi nedeniyle daha da önem kazanmaktadır. Ölüm öncesi ve ölüm sonrası veriler arasında yeterli karakteristik özelliklerin bulunduğu ve açıklanabilir olduğu her durumda bunun bir pozitif kimliklendirme olduğu kabul edilir. ${ }^{8}$

\section{B - Dental görüntülemeler:}

Mukayese için önceki kayıtların mevcut olmadığı durumlarda kimliklendirme işlemine alternatif bir yardım olarak röntgenler kullanılır. Ölen kişinin radyografik görüntüleri elde edilebilir ve şüphelinin ölüm öncesi radyografik görüntüleri ile karşılaştırılabilir. Tarihsel olarak bakıldığında röntgenlerin adli amaçla ilk defa 1896 da bir maktülün kafası içindeki mermi çekirdeğinin varlığını ortaya çıkarmak için kullanıldığı görülmektedir ki bu da Rontgen tarafından X ışınlarının keşfedilmesinden tam bir yıl sonradır. Dental radyografiler adli kimliklendirme için önemli bilgiler verirler. $\mathrm{Bu}$ radyografilerde kullanılan parametreler dişin ve kökün şekli, mevcut dişler, eksik dişler, kırık kökler, 
süpernümerer dişler atrisyon, abrazyon, fraktür gibi özellikler, periodontal hastalık nedeniyle kemik rezorpsiyonu, kemik patolojisi, diastemalar, çürükler, endodontik tedaviler, intraradiküler ve intrakoronal postlar ile dental protezlerdir. Geleneksel radyografiler kuronun şekli ve boyutunu, pulpa anatomisini, alveolar kretin durumunu vs. gösterir. ${ }^{9}$

Bilgisayarlı tomografi (CT) görüntüsü bölgenin enine kesitlerini ortaya çıkarır ve buradan çeşitli görüntüler üretir. Antemortem CT görüntüleri kraniometrik noktaların tam yerinin bulunduğu ve ölçümlerin doğru olarak yapıldığı dikkate alınarak postmortem görüntü kopyasının yapımında kullanılabilecek bilgiler verir. ${ }^{10}$

Frontal sinüs şekli de kişiye özeldir ve kimliklendirmede kullanılan bir parametredir. Frontal sinüs görüntülerinin karşılaştırılması için kullanılan parametreler boyutundaki, şeklindeki simetrisindeki, dış sınırlarındaki farklılıklar ile septum ve hücrelerin varlığı ve sayısıdır. ${ }^{9}$

Radiovisiograf (RVG) gibi dijital görüntüleme teknikleri antemortem ve postmortem görüntülerde diş köklerinin ve onları destekleyen çevre dokuların doğru bir şekilde konumsal ve üç boyutlu analizlerini yapmaya olanak verir. ${ }^{11}$ Görüntülerin aktarılması, döndürülmesi, ölçeklendirilmesine yardımc olan ve antemortem ve postmortem radyografiler arasındaki gerçek uyumu kolaylaştırarak yeni görüntünün gerekli düzenlemesini yapan pek çok bilgisayar programı geliştirilmiştir. $^{12} \mathrm{Bu}$ yüzden radyolojik tekniklerin kullanılması, gizli kalmış dental bilgilerin adli diş hekimliğinde kullanılmasına olanak sağlar.

Kişisel karakteristik özellikleri gösteren yüz fotoğrafları, gülümseme fotoğrafları ve video kayıtları da adli identifikasyon için fayda sağlar. Ortodonti, bu konuda kişinin gülüşünü belirleyen dental ve çevresel dokuların geniş kapsamlı bir klinik doküman kaynağıdır. Dijital kameraların popüler hale gelmesiyle, tedavinin planlanması ve uygulanması için ekstraoral ve intraoral fotoğrafların kullanımındaki artış, adli kimliklendirme için çok daha fazla veri sağlamaktadır. ${ }^{13}$

\section{C - Isırık İzi Analizleri:}

İnsan dokusu üzerindeki ısırık izleri suç, cinsel istismar ve çocuk istismarı ile bağlantılı durumlarda ve cinayet, saldırı, tecavüz, kavga gibi olaylarda gözlemlenebilir. Saldırganın mağduru ısırdığı veya mağdurun savunmak için saldırganı ısırdığı durumlarda da görülebileceğinden, ısırılan mağdurun vakanın şüphelisi de olabileceği unutulmamalıdır. Erkek mağdurların sıklıkla omuz ve kol bölgesinden, kadın mağdurların ise göğüs, kol ve bacaklardan ısırıldığı gözlemlenmiştir. ${ }^{14}$ Isırma yüzeyindeki izler benzersizdir ve ısırma fonksiyonuna bağlıdır. Aynı zamanda kırık, rotasyon, eksik veya fazla diş gibi dentisyondaki kişisel özellikleri de gösterir. İlaveten dental arkın genişliği, saldırganın yaşı ile de ilgili olabilir. Isırık izinin anatomik lokasyonunun niteliği ve çeşitliliği kişinin kimliğinin belirlenmesinde önem taşır. İnceleme sırasında ısırılan mağdurun yaş, isim, cinsiyet, tarih gibi demografik bilgileri, izin lokasyonu, boyutu, şekli rengi, yaranın tipi belirlenmeli ve ısırık yerinden svap alınmalıdır. Çıplak göz ile görülemeyen ısırık izi vakaları ultraviyole ışını tekniği ile görülür hale getirilebilir. Isırıcı şüpheliden delil toplanması ise, olayın ayrıntılı hikayesi, fotoğraflar, detaylı intraoral ekstraoral muayene ve her iki arkın da iyi alınmış ölçülerini içermelidir. ${ }^{15}$

Isırık izlerinin karşılaştırılmasında şekil-boyut ölçümü ve dişlerin pozisyonlarının belirlenmesi gibi analizler yapılır. İzlerin şeffaf bir yüzey üzerinde oluşturulması, en yaygın karşılaştırma yöntemidir. Ayrıca, çalışma modelleri, mum izleri, kserografik görüntüler, radyoopak mum izleri ve kompüter metotları da kullanılır. ${ }^{16}$ Bütün bunlara ilaveten ısırık izinden bakteri genotiplemesi, tükürükten DNA elde edilmesi de adli araştırmaların temelini oluşturan en güncel metotlar haline gelmiştir. ${ }^{17}$

\section{D- DNA Analizleri:}

DNA analizi adli odontoloji alanında kullanılan daha yeni bir yöntemdir ve ISı etkisi, travma, otolitik süreçler, bozulmalar ve analizdeki zorluklardan dolayı bilinen kimlik belirleme yöntemlerinin başarısız olduğu durumlarda önem kazanmaktadır. DNA tiplemesini gerçekleştirmek için kullanılabilecek kan, sperm, kemik, diş, saç ve tükürük gibi birçok biyolojik materyal vardır. İhmal edilebilir miktarda kaynak materyalden bile belirli bir DNA dizisinin enzimatik çoğaltılmasına izin veren polimeraz zincir reaksiyonunun (PCR) ortaya çıkmasıyla, DNA analizi kullanılarak yapılan adli kimliklendirmeler, giderek daha fazla popüler hale gelmektedir. ${ }^{17}$

Adli bilimler alanında genomik ve mitokondriyal DNA kullanılır. Genomik DNA, insan vücudundaki her hücrenin çekirdeğinde bulunur. Dişler mükemmel bir genomik DNA kaynağıdır. Mitokondriyal DNA ise (mtDNA), ekstrakte edilecek DNA örneklerinin çok az veya bozulmuş olduğu durumlarda ya da, iskeletten elde edileceği durumlarda kullanılabilir. ${ }^{16}$ Elde edilen DNA, daha sonra eldeki kan, saç, giysi, svap veya biyopsi gibi antemortem veya postmortem örnekler ile karşılaştırılır. ${ }^{19}$

Halen gerçekleştirilen DNA profili testleri 
güvenilirdir ve kişinin cinsiyeti, fiziksel özellikleri ve etnik kökeni hakkında bilgi sağlar. Bu testler insan kimliğinin araştırıması ve babalık tayini gibi durumlarda mahkemelerde yasal kanıtlar olarak kabul edilmek- tedir. ${ }^{18}$ DNA profillemesinde vakanın durumuna göre daha ileri DNA profilleme teknikleri kullanılmaktadır. ${ }^{19}$

\section{E - Şelioskopi:}

Şeiloskopi, dudak izlerine göre insanların kimlik belirlemesini yapan bir adli araştırma tekniğidir. Antemortem kayıt olarak dişler kullanılırken, bazen o dişin mevcut olmaması veya yapılmış olan restorasyonun bozulmuş olması, antemortem ve postmortem kayıtların karşılaştırılmasında güçlük yaratabilir. ${ }^{6} \mathrm{Bu}$ zorlukların üstesinden gelmek için, değişmez bir parametre kullanılmalıdır. Parmak izi, avuç içi ve ayak izleri gibi dudak izleri de benzersizdir ve bir kişinin hayatı boyunca değişmez. Dudaklardaki ince oluk ve çizgilerin meydana getirdiği dudak izi adli araştırmalar için yeterli bilgi sağlar. Dudak izleri, olay yerinde doğrudan ölen kişinin dudaklarından ya da kıyafet, bardak, sigara, vs gibi nesnelerden alınabilir.

Dudak izlerinin, dudaktaki postmortem değişimlerden kaynaklanabilecek hataların önlenmesi için ölümden sonra ilk 24 saat içinde alınması gerekir. Dudak izlerinin biçimi ağzın açık veya kapalı olmasına bağlıdır. Kapalı ağız pozisyonunda dudak belirgin çizgiler gösterir; açık ağız pozisyonunda ise bu çizgiler nispeten düzensizdir ve yorumlanması zordur. ${ }^{20}$ Dudaktaki mukosel gibi patolojik durumlar, ameliyat sonrası değişiklikler, ön dişlerin kaybına bağlı destek kaybı, dudak yüzeyinde kalıntı veya sıvı varlığı, kalın bir ruj tabakası veya iz alınırken uygulanılan sellofan bandının aşırı gerilmesi dudak izinde değişiklik yaratabilir. ${ }^{6}$ Dudak izi sellofan bant veya basınca duyarlı bir bant kullanılarak elde edilebilir. Dudak izi cinsiyet tayininde de mandibular kanin indeksi kadar doğru sonuçlar vermiştir. ${ }^{21}$ İnsan vücudunda doğal olarak bulunan bu gibi bazı özellikler son zamanlarda daha çok dikkat çekmiştir biyometrik yöntemleri daha önemli hale getirmiştir. ${ }^{20}$

\section{F - Rugoskopi}

Damaktaki ruga adı verilen kabartılar benzersizlikleri nedeniyle travma gibi sebeplerle diş kaybı durumunda kimlik belirlenmesi için alternatif bir yöntem olarak kullanılabilirler. Ruga oral kavitenin içinde yer aldığından ve dil ve yanak dokusu ile korunduğundan, dış etkenlere karşı bozulmadan durabilecek bir durumdadır. Ruga şekli yaş ve ortodontik hareketler, diş çekimi, yarık damak ameliyatı, periodontal cerrahi, gömük kanin operasyonu gibi diğer çevresel etkilerle birlikte değişebilir. ${ }^{6}$ Rugae analizi, maksiller arkın muayenesi ve fotoğrafları, bilgisayar yazılım programları, Stereoskopi (palatal rugae'nin 3 boyutlu görüntüsünün yapılabildiği) gibi yöntemlerle yapılabilir. $^{22}$

\section{G - Cinsiyet tayini}

Cinsiyet tayini çalışmalarının kimliği belirsiz iskeletlerde çok önemli bir rolü vardır. Cinsiyet tayini için pelvis kemiği, femur, tibia gibi uzun kemikler ve kostaların yanı sıra kafatası ve dişler de kullanılır. Kafatası ve dişler kullanılarak yapılacak olan cinsiyet tayininde şu metodlar uygulanır:

Kranium morfolojisi, kraniofasial morfoloji ve ölçümler: Kafatası ve mandibulanın morfolojisi, mastoid, orbitalar, gonion açısı, frontal sinüsler, ramus, kondiller ve simfiz bölgesi incelenir.

Diş morfolojisi ve diş boyut ölçümleri: Kaninler cinsiyet tayininde en belirleyici dişlerdir. Cinsiyet tayininde en çok kullanılan yöntem mandibular kanin indeksidir. ${ }^{23} \mathrm{Bu}$ yöntemde mandibular kaninler arası mesafe ve kaninlerin mesio-distal genişliği ölçülür ve bu iki ölçümün birbirine oranı hesaplanarak kişinin cinsiyeti tayin edilir. Ayrıca dişlerin mesio-distal ve bukko-lingual boyutları incelenerek de cinsiyet belirlenebilir. ${ }^{24,25}$

\section{H - Yaş Belirleme}

Adli tıpta yaş tayini canlılarda hukuk ve ceza açısından çok önemli bir konudur. Adli bilimlere göre yaş tayini sadece kişinin fiziksel tanımı veya kimliğinin saptanmasında değil, kaza ve suç ile ilgili durumlarda da belirleyici bir rol oynar. Kimliği belirsiz bir ölünün kimliğinin saptanmasında geçerli bir doğum belgesinin bulunmadığı veya şüpheli olduğu durumlarda ve adli makamlar tarafından yaş belirlenmesi istenebilir. Bu durumlarda kişinin gerçek yaşı adli tıp uzmanları ve adli diş hekimleri tarafından tespit edilir. Yaş belirleme kriterleri ikiye ayrılır:

1-Diş gelişimine bağlı değişiklikler: Diş gelişiminin başlaması ve oral kavitede ortaya çıkması ile görülen değişiklikler. (Sert doku formasyonu, süt dişleri, kalıc dişler ve 3.molar erüpsiyonu)

2- Dejeneratif değişiklikler: Erüpsiyondan aşınma başlayıncaya kadar ortaya çıkan değişiklikler: Bunlar yaş ile ilgilidir ve dişlerdeki aşınma arttıkça sekonder dentin depozisyonu da artar.

$\mathrm{Bu}$ kriterlere göre yaş belirlemede değişik metodlar kullanılır:

a) İntrauterin yaşamdan 20-25 yaşına kadar: Radyolojik, Morfolojik ve Sayısal Teknikler 26,27 
1- Mineralizasyonun başlaması

2- Kuronun tamamlanması

3- Dişlerin erüpsiyonu

4- Apekslerin kapanması Teknikler 28

b) 20-25 yaşından sonra: Radyolojik ve Sayısal

1- Atrisyon

2- Periodontal değişiklikler

3- Sekonder dentin

4- Sement apozisyonu

5- Kök rezorbsiyonu

6- Dentin transparanlığ

c) Daha ileri yaşlarda: Radyolojik, Morfolojik, Kimyasal ve Histolojik Teknikler 29,30

1-Mineralizasyonun elektron mikroskobu ile incelenmesi

2-Dentindeki aspartik asit değişiminin ölçülmesi

II. Adli dental kimliklendirmede yeni kavramlar:

A - Fasial rekonstrüksiyon:

Geçmişten bu güne kadar dünyadaki bütün insanlarda yüz yapısı ve şekli kişiye özgü olmuştur ve bu nedenle insan kimliği için çok önemlidir. Adli bilimlerde de önemli bir rol oynar, çünkü ölen kişinin yüzünde bir değişiklik yoksa, kişinin kimlik tespiti adli tıp uzmanlarına ihtiyaç duymadan kolayca yapılabilir. Adli diş hekimliği sadece kişinin yüzünün bir şekilde tahrip olduğu durumlarda gereklidir. Adli tıp uzmanları, bulunan insan kalıntılarını (bütün veya parçalanmış haldeki bedenleri) tanımlamak için çalışırlar. Çoğu zaman büyük felaketlerde ve kazalarda, ölü kişinin vücudu parçalanmış veya iskelet haline gelmiş olarak bulunabilir. Bu gibi durumlarda, korunan tek kısım kafatası veya diğer kemikler olabilir. Kafatasları milyonlarca yıl bile değişmeden kalabilir ve kimliklendirme için benzersiz bir materyal olabilir. Kranial görünüm, bireyin cinsiyetini belirlemede çok yardımcıdır. Fasial rekonstrüksiyon geçmiş yıllarda kafatasından kişinin yaşı ve cinsiyeti belirlendikten sonra aynı kafatası üzerinde daha önceden belirlenmiş olan ve her topluma özgü doku kalınlıkları verilerini kullanarak seramik hamuru gibi malzemelerle tahmini bir yüz şekli oluşturmak esasına dayanıyordu. Bu yöntem bugün de kullanılmakla beraber, son yıllarda bilgisayar yardımıyla yapılan fasial rekonstrüksiyonlar daha da önem kazanmaya başlamıştır.

Lazer video kamera ile yapılan bilgisayarlı yüz rekonstrüksiyon yöntemi ve CT taraması ile kafatası verileri 3 boyutlu yüzey olarak görüntülenir. ${ }^{31}$ Yüz bil- gisayar yazılımı yardımıyla çizilebilir. 3D-BT görüntülemenin, doğrudan $\mathrm{CT}$ kesitleri ve 2D-BT görüntü rekonstrüksiyonunda yapılan görüntülemeden daha doğru olduğu bulunmuştur. ${ }^{32}$ Yüzün resmi kesin olarak oluşturulamasa bile, bu yöntem kişiyi tanımlamada çok yardımcı olmaktadır

\section{B - Protez Tanımlama Yöntemleri:}

Dişlerinin tümü ya da çoğunluğu mevcut olan kişilerde, çeşitli yöntemlerle dişlerden kimlik tespiti yapılabilirken, dişsiz kişilerde bu türden bilgilerin eksik olması nedeniyle dental tespit yapılamaz. Bu gibi durumlarda, tespite yarayacak tek kalıntı kişinin protezleridir. Herhangi bir işareti olmayan bir protez, adli diş hekimliğinde ya çok az kullanılabilir veya hiç kullanılamaz. Protezler bir kişinin pozitif kimliğini, sadece işaretlenmişse ortaya çıkarabilir. Protezin etiketlenmesi en kolay ve güvenilir tanımlama yöntemlerinden biridir. Protez etiketleme yöntemleri iki kategoriye ayrılmaktadır: Protezi yüzeyden veya içinden işaretleme yöntemi.

Yüzey işaretleme yöntemleri, protezin karalanması, kazınması veya kabartma harflerle üstünün işaretlenmesidir. İçinden işaretleme yöntemleri arasında ise Metal tanımlama bantları, bilgisayarla yazdırılan protez mikro etiketleme sistemi, hasta fotoğrafının gömülmesi, Protez barkodlama, T-Bar, lazerle kazıma, mercekli kart sistemi (bir açıdan bakıldığında, hastanın adı, cinsiyet ve yaşı, diğer açıdan bakıldığında adresi ve kimlik numarasını gösterir), radyofrekans tanımlama etiketleri, elektronik mikro-çipler vardır. ${ }^{33,34}$ Her iki protez işaretleme yöntemi total ve parsiyel protez- lerde, yer tutucularda ve çıkarılabilir ortodontik apa- reylerde kullanılabilir. Bu iki kategori arasında, yüzey yöntemlerinin uygulanması nispeten daha kolaydır ve ucuzdur. Tek dezavantajı kolayca aşınması ve tekrar uygulanması gerekliliğidir. İçinden işaretleme yöntem- leri daha kalıcı olsa da, protez yapısını zayıflatabilir ve gözenek yapabilir. ${ }^{35}$

\section{C - Mukayese mikroskopları:}

Adli bilimlerde mikroskop kullanımının delillerin doğru değerlendirilmesinde önemli bir rolü vardır. Dişlerin mikroskop altında muayenesinde $\mathrm{Y}$ kromatin varlığı cinsiyet tayini için belirleyicidir. 4 Faz kontrast mikroskobu ile yapılan sement birikim analizleri yaş tahmini için kullanılır. Örneklerin karşılaştırılması durumunda ise konvansiyonel mikroskop odaklanmayı düzeltmek ve farklı görüntüler elde etmek için faydalı olmakla beraber fazla zaman almaktadır. Bu problemleri çözmek için Sanal Karşılaştırma Mikroskobu (VCM) geliştirilmiştir. Bu mikroskop numunelerin aynı anda 
analiz edilmesine olanak sağlar. Bölünmüş bir görünüm penceresine sahip ve optik köprü ile bağlanmış iki mikroskoptan oluşmaktadır. Bu cihaz ile iyi bir görüntü sağlanarak herhangi bir yerde önemli işaretler bulmak mümkün olur. ${ }^{36}$

\section{D - Dil izleri:}

Dil, şekli ve yüzey dokularındaki özellikleri kişiye özgü olan ve muayene için vücuttan dışarı çıkabilen ve tek iç organdır. Adli diş hekimliğinde dil izinin kullanılması şu an için oldukça yeni bir uygulamadır. Bu tekniğin başarılı olması için, antemortem fotoğraf veya dil izinin mevcut olması gerekir. Dil morfolojisi her bir birey için farklı detaylar içerir ve aljinat ölçü ile bu detaylar incelenebilir hale getirilir. Varsa dilin fotoğraf görüntüsü de incelenir. ${ }^{37}$ Son zamanlarda adli bilimlerde dil incelemesi için biyometrik dil şablonu oluşturulmuştur. Bu şablon dilin sağ yan, sol yan ve ön görünümü gibi 3 taraflı görüntüsünün alınması ile ve papillerin yerleri ve şekillerinin belirlenmesi ile oluşturulur. $^{38}$

\section{SONUÇ}

Adli odontoloji hızla gelişen ve gelişmeye çok açık bir diş hekimliği dalıdır. Olay yeri incelemesinde adli diş hekimleri diş kanıtlarını araştırmak ve yorumlamakta önemli bir rol oynarlar. Diş anatomisinin eşsiz yapısı, özel restorasyonlar ve teknikler uygun bir şekilde değerlendirildiği takdirde oldukça doğru sonuçlar verir. Karşılaştırmayı kolaylaştırmak için mevcut olan tüm verilerin bilgisayar ortamında saklanmasına ve özellikle antemortem diş kayıtlarının düzgün olarak tutulmuş olmasına özen gösterilmelidir. Her diş hekimi gerektiğinde adli makamlara yardımcı olabilmek için adli diş hekimliği ile ilgili uygulamalar hakkında bilgi sahibi olmalı ve bu sorumluluğu duymalıdır. Diş hekimliği öğrencileri ve teknisyenleri de mevcut tekniklerin farkında olmalı ve bunların adli diş hekimliğinde kullanılacağı bilincinde hareket etmelidir. Adli dental kimliklendirme için yeni tekniklerin geliştirilmesini sağlayacak yeni araştırmalar teşvik edilmelidir.

NOT: Çalışmada herhangi bir yazar, kurum ya da kuruluş ile çıkar çatışması içerisinde bulunmamaktadır. Makale daha önce hiçbir yerde yayınlanmamış ve yayınlanmak üzere işlem görmemektedir

\section{KAYNAKLAR}

1. Keiser-Nielsen, S. "Dental Identification: Certainty v. Probability" Forensic Sci. 1977;9:87-
10

2. Divakar KP. Forensic Odontology: The New Dimensions in Dental Analyses. Int J Biomed Sci 2017;13:1-5

3. Auerkari E. Recent Trends in Dental Forensics. Indonesian Journal of Legal and Forensic Sciences 2008;1:5-12.

4. Narendra NS, Owais G, Tasneem SA, Saima S. Exploring Trends in Forensic Odontology. J Clin Diagnostic Res 2014;8:28-2

5. Balachander N, Babu NA, Jimson S, Priyadharsini C, Masthan K. Evolution of Forensic Odontology: An overview. J Pharm Bioall Sci 2015;7:76-4

6. Zakirulla M, Allahbaksh Meer. Modern Tools in Forensic Dentistry. J Contemp Dent 2011;2:28-4

7. Sudheer BB. Forensic Dental Identification: Practice in Indian Context Compared to Western Countries. Journal of Forensic Science and Medicine 2016;2:44-3

8. Puneeth $\mathrm{H}$, Sureshchandra S, Lokendra G. Role and Importance of Forensic Odontology in Identification. International Interdisciplinary Journal of Scientific Research 2014;1:64-5

9. Carvalho SPM, Silva RHA, Lopes Jr C, Sales-Peres A. Use of Images for Human Identification in Forensic Dentistry. Radiol Bras 2009;42:125-5

10. Rocha SS, Ramos DLP, Cavalcanti MGP. Applicability of 3D-CT Facial Reconstruction for Forensic Individual Identification. Pesqui Odontol Bras 2003;17:24-4

11. Wood RE, Kirk NJ, Sweet DJ. Digital Dental Radiographic Identification in the Pediatric, Mixed and Permanent Dentitions. J Forensic Sci 1999;44:910-6.

12. Hubar JS, Carr RF. Computed Dental Radiography Used to Reproduce Antemortem Film Position. J Forensic Sci 1999;44:401-3

13. Silva RF, Pereira SD, Prado FB, Daruge E. Forensic Odontology Identification Using Smile Photograph Analysis-Case Reports. J Forensic Odontontostomatol 2008;27:12-5

14. Giannelli C. Bite Mark Analysis. Faculty Publications 2007. Paper 153.

15. Kalyani B, Deepak B, Pooja R, Mayura P, Rohit $P$, Jagadeesh H.G, Amita S. An Overview of Bite mark Analysis. J Indian Acad Forensic Med 2012; 34:61-5

16. Velden AV, Spiessens M, Willems G. Bite Mark Analysis And Comparison Using Image Perception Technology. J Forensic 
Odontostomatol 2006;24:14-7.

17. Ricardo HAS, Jamilly OM, Rodolfo FHM, Rogério NO. Human Bite Mark Identification and DNA Technology in Forensic Dentistry. Braz J Oral Sci 2006;5:1193-4

18. Pankaj D, Sonia S, Pooja R, Kalyani B, Deepak B, Mukesh Y. DNA Profiling in Forensic Dentistry. J Indian Acad Forensic Med 2012;34:156-3

19. Sandeep SM, Priyanka A, Pallavi V. Dental DNA Finger-printing in Identification of Human Remains. Annuals of Dental Specialty 2013;1:163

20. Reddy KV. Lip prints: An Overview in Forensic Dentistry. J Adv Dental Research 2011;2:17-3

21. Reshma PK, Radhika T, Vidhya R, Malathi N. Gender Determination: Role of Lip Prints, Finger Prints and Mandibular Canine Index. Experimental And Therapeutic Medicine 2016;11:2329-3

22. Krishnappa S, Srinath S, Bhardwaj P, Mallaya CH. Palatal Rugoscopy: Implementation in Forensic Odontology- A Review. J Adv Med Dent Sci 2013;1:53-6

23. Rao NG, Kotian MS. Mandibular Canine Index-A Clue for Establishing Sex Identity. Forensic Sci Int 1989;42:249-5

24. Karaman F. Use of diagonal teeth measurement to predict gender in a Turkish population. J Forensic Sci 2006;51:630-5

25. Ates $M$, Karaman F, İscan MY, Erdem TL. Sexual differences in Turkish dentition. Legal Medicine 8 2006;8:288-4

26. Schour I., Massler M. Studies in tooth development: The growth pattern of the human teeth. J Am Dent Assn 1940;27:1918-13

27. Demirjian A, Goldstein $H$ and Tanner JM. A new system of dental age assessment. Human Biology. 1973;42:211-16

28. Gustafson G. Age determination on teeth. Journal of Am Dent assoc.1950;41:45-9

29. Ohtani S, Yamamoto K. Age Estimation Using the Racemization of Amino Acid in Human Dentin, J Forensic Sci, 1991;36:792-8

30. Canger EM, Arslan S. Adli diş hekimliğinde radyolojinin kullanımı. Atatürk Üniv. Diş. Hek. Fak. Derg. J Dent Fac Ataturk Uni.2013;23:252-8

31. Verze L. History of Facial Reconstruction. Acta Biomed 2009;80:5-7

32. Rocha SS, Ramos DLP, Caval CM. Applicability of 3D-CT Facial Reconstruction for Forensic
Individual Identification. Pesqui Odontol Bras 2003;17:24-4

33. Thomas T, Muruppel AM, N Dinesh, Gladstone $S$, George N. Dentures in Forensic IdentificationA Review of Methods and Benefits. J Adv Med Dent Sci 2014;2:85-9

34. Manu $R$, Kusum $Y$. Denture Identification Methods: A Review. IOSR Journal of Dental and Medical Sciences 2014;13:58-3

35. Sandeep KB, Talib AN, Sabzar A, Shazia M, Shazana N, Ashfaq Y. Denture Identification Methods: A Review. International Journal of Health Sciences \& Research 2013;3:100-4

36. Sumalatha S, Padmaja S, Prafulla T. "Every Contact Leaves Its Trace"-Insight into Recent Advances of Forensic Odontology. Journal of Cancer Treatment and Research 2015;3:1-7.

37. Corina LS, Marius FP, Lavinia SC. Preliminary Study on the Tongue-Based Forensic Identification. Rom J Leg Med 2014;22:263-3

38. Manoj D, Manish M. An Extraction and Recognition of Tongue-Print Images for Biometrics Authentication System. International Journal of Computer Applications 2013;61:36-6

\author{
Yazışma Adresi \\ Dr. Dt. Feryal KARAMAN (DMD, Ph.D) \\ İstanbul Üniversitesi Cerrahpaşa \\ Adli Tıp Enstitüsü \\ Fatih/ İstanbul \\ e-mail: feryalkaraman@hotmail.com
}

